\title{
US Mediation in Greek-Turkish Disputes since 1954
}

\author{
Theodora Kalaitzaki
}

Greece and Turkey emerged from the Second World War as solid members of the Western alliance, their bilateral territorial disputes appearing settled. The conflicts dating back to Ottoman times seemed memories, fading into a new tradition of peace and friendship established in the early 1930s in the historic reconciliation of the powerful and charismatic leaders, Eleftherios Venizelos and Kemal Atatürk.

In the aftermath of the Second World War both had sided with the Western countries, and with their participation in the Western European institutions (the Council of Europe and the North Atlantic Treaty Organization) they became "officially" part of the Western bloc led by the United States against the Eastern bloc of communist states.

In the difficult Cold War environment the three allies seemed to have harmonious relations focusing on the external communist danger coming from the north. This cordial era ended in 1954 with the eruption of the Cyprus problem, a bilateral conflict between Greece and Turkey that persisted into the next decades with the emergence of the Aegean dispute. After the emergence of the Cyprus dispute, both states expected the involvement of the United States, aiding one against the other. The United States to a certain extent unwillingly became the "mediator" between the two states, and this task continues until today.

In this essay I summarize the historical background of Greek-Turkish relations during the interwar years, the political and security challenges the

Theodora Kalaitzaki, a resident of Athens, recently received her $\mathrm{PhD}$ in international relations at Bilkent University in Ankara, Turkey. 
two states faced at the end of the Second World War, and the beginning of the alliance ties among the United States, Greece, and Turkey. I also examine the most serious Cyprus and Aegean crises along with American mediation and solution efforts. The last part is devoted to US involvement in the post-Cold War era.

\section{Greek-Turkish Relations at the End of the Second World War}

The settlement reached at Lausanne on 24 July 1923, after the GreekTurkish war of 1919 to 1922 , solved territorial and minority issues and laid the foundations for peaceful relations between Greece and Turkey. ${ }^{1}$ Exhausted by many years of wars, both countries faced enormous problems of domestic reconstruction. The two states were prepared to develop good and stable relations and both pursued these goals during the interwar years.

An additional factor in the development of détente between Greece and Turkey, which gained ground in the late 1920s, was a growing perception of common defense interests. While Greece and Turkey still mistrusted each other to some extent, both of them had serious concerns about Bulgaria's ambitions to gain access to the Aegean as well as about Italy's intentions in the eastern Mediterranean. ${ }^{2}$

In June 1930, Greece and Turkey signed an agreement that settled all the remaining disputes arising out of the exchange of populations and the value of properties left behind. Although the terms of the agreement were criticized

1. At Lausanne, Turkey's boundary with Greece was set at the Evros (Maritsa) River, which separates western and eastern Thrace. Greece retained its sovereignty over the Aegean islands with two exceptions: Gokceada (Imvros) and Bozcaada (Tenedos), which guard the entrance to the straits, were restored to Turkey (Lausanne Treaty: Part 1: article 3). The islands of the eastern Aegean, because of Turkish security concerns, were to be demilitarized (Lausanne Treaty: Part 1: article 13). In addition, the Lausanne Treaty arranged the fate of the Greek and Turkish minorities. The protocol signed on 30 January 1923 at Lausanne provided for the compulsory exchange of the Greeks of Asia Minor and the Turks of Greece, with two exceptions - the Greeks of Istanbul and the Muslim Turks and Pomaks of western Thrace in Greece (articles 1-2). The treaty safeguarded the cultural and educational rights of the minorities (articles 40-43). See Lausanne Treaty (in Greek) (Athens: Papazisis), 45-50, 71-86; Sina Sukru Gürel, Turkish-Greek Relations in a Historical Context (in Turkish) (Ankara: Ümıt, 1993), 30-4; Mehmet Gönlülbol et al., Events of Turkish Foreign Policy (Ankara: Cem Ofset, 1996), 48-59; Kemal Ari, The Great Exchange: The Forced Migration to Turkey (in Turkish) (Istanbul: Tarih Vakfi Yurt, 1995).

2. Konstantinos Svolopoulos, Greek Foreign Policy, 1900-1945 (in Greek) (Athens: Estia, 1994), $211-32$. 
in Greece as too favorable to Turkey, Venizelos attached a high priority to a policy of conciliation with the Turks. The mutual understanding between the two countries was further enhanced with the Treaty of Neutrality, Conciliation, and Arbitration as well as with a protocol providing for parity of naval armaments, signed between Venizelos and Izmet Inönü in October 1930. ${ }^{3}$

In September 1933, the two countries signed a friendship pact guaranteeing the inviolability of their borders and committing them to consult each other on matters of common interest. During the following year, the two countries took another step in collaboration when they joined the Balkan Entente with Yugoslavia and Romania. By joining the Balkan Entente, Greece and Turkey hoped to discourage anticipated pressures from Italy or Germany. ${ }^{4}$ However, neither this nor subsequent bilateral Greek-Turkish agreements deterred Italy and Germany from pursuing their ambitions to penetrate and control the Balkans. In any case, Greece and Turkey were unprepared to undertake obligations that might draw them into war with a Great Power. Thus, when German troops occupied Greece, following the unsuccessful Italian invasion in October 1940, Turkey remained neutral. ${ }^{5}$

\section{The Beginning of the Triangular Relationship after the End of the Second World War}

After the unconditional surrender of the Axis Powers in 1945, the need to fill the resulting power vacuum led to the appearance of diverging national

3. Areti Tounta-Fergadi, Issues in Greek Diplomatic History (in Greek) (Athens: Paratiritis, 1986), 243-9; Gürel, 35-52.

4. Konstantinos Svolopoulos, The Balkan Pact and Greek Foreign Policy, 1928-1934 (in Greek) (Athens: Estia, 1974).

5. Turkey's decision to stay neutral during the Second World War disappointed Greece. Greek leaders felt that Turkey was under an obligation to come to Greece's aid under the terms of the Balkan Entente and subsequent Turkish assurances to help Greece. But Turkey continued to recognize the Greek government in exile and offered Greece help in terms of food and other relief items. One other issue that strained Greek-Turkish relations during the Second World War was Turkey's imposition of an emergency capital levy called varlik vergisi on non-Muslim communities in Turkey, including the Greeks, in November 1942. The Turkish government justified the tax on the grounds that it needed to raise revenue to finance Turkey's growing military expenditures. However, Greeks and other minorities complained that they were assessed higher levies than Turks, and the Greek government lodged protests to Ankara. The Turkish government removed the tax a year after its imposition. See Alexis Alexandris, The Greek Minority of Istanbul and Greek-Turkish Relations, 1918-1974 (Athens: Center for Asia Minor Studies, 1983), 211-33. 
interests inside the wartime alliance. The intentions of the Allies became diametrically opposed after the end of the Second World War. The USSR, for instance, which emerged as an important power, wished to expand its influence and establish "friendly" regimes in all of the states close to its borders. In contrast, the United States, under President Harry Truman's leadership, initially followed Franklin Roosevelt's policy of maintaining the alliance and acting together within a system of collective security. But the United States soon realized that the wartime harmony had vanished.

In southeastern Europe Greece found itself in the middle of a chaotic economic and political situation upon liberation in October 1944. The communist and anticommunist Greek resistance groups had been waging a conflict, aiming at the political control of the country. ${ }^{6}$ In comparison, Turkey, which had managed to remain out of the war, emerged with its economy intact and without crises in its domestic political institutions. The Soviet Union, in its effort to expand its influence in southeastern Europe, indirectly provided support to the Greek communists in the civil war, demanded of Turkey naval bases in the Bosporus and the Dardanelles, and made claims over Kars and Ardahan.

These attempts were perceived as revisionist objectives in the Greek-Turkish area. Therefore, the governments of Greece and Turkey sought to secure commitments, peacetime entanglements, active presence, and guarantees from the West, and especially from the United States, to contain Soviet penetration. Various Greek cabinets did so with the utmost urgency and with no other options while successive Turkish governments sought US aid after a careful weighing of all options available.

The US commitment toward Greece and Turkey was undertaken in the context of Washington's Cold War political strategy. The United States had become convinced of Josef Stalin's intentions to "export communism," and

6. Throughout the occupation years a significant resistance movement developed and carried out acts of sabotage and harassment against the Germans. The most important groups were EAM (National Liberation Front) and its military arm, ELAS (National Popular Liberation Army), and EDES (National Republican Greek League). EAM and ELAS were dominated at the leadership level by members of the Communist Party. However, other parties and agrarian and socialist groups participated in EAM, and the overwhelmingly majority of the rank and file were not communists. EDES was republican and anticommunist in orientation. Giannis Gianopoulos, The Post-War World: Greek and European History, 1945-1963 (in Greek) (Athens: Papazisis, 1992), 191-221. 
Britain had notified the United States of its inability to continue assistance to Greece and Turkey.

On 12 March 1947, President Truman announced what later became known as the Truman Doctrine, declaring that the United States was to support free peoples who were resisting attempted subjugation by armed minorities (Greece) or by outside pressures (Turkey). ${ }^{7}$ If Greece fell under the control of an armed minority, the effect on Turkey would be immediate and serious, and the ensuing confusion and disorder might well spread throughout the Middle East. Truman asked for an allocation of $\$ 400$ million of aid to be spent on supporting the shattered economy of Greece and providing military aid to both Turkey and Greece. America's institutional and structural presence in Greece and Turkey strengthened in the early 1950s with the accession of both countries to NATO and the Council of Europe and the signing of separate bilateral agreements regulating the status of US bases in both countries.

The objectives of both Greece and Turkey were fulfilled with their participation in these organizations. Greece and Turkey could now institutionalize their relationship with other Western states. Through formal participation on the basis of legal equality in these multilateral organizations, both Greece and Turkey gradually developed legal, political, and psychological filters, muting direct intervention and maximizing perceptions of sovereignty and independence with predictable political benefits at home.

In this framework, Greek-Turkish relations were influenced quite positively. Bilateral relations became stabilized as identical Greek and Turkish security concerns vis-à-vis the Soviet Union prompted them to establish closer ties with the West. The warming trend in Greek-Turkish relations was reflected in the statement by Turkish President Celal Bayar during a state visit to Greece in January 1954, when he described Greek-Turkish cooperation as "the best example of how the two countries who mistakenly mistrusted each other for centuries have agreed upon a close and loyal collaboration as a result of recognition of the realities of life." 8

As long as Greek and Turkish interests coincided, as they did for nearly

7. Henry Kissinger, Diplomacy (London: Simon and Schuster, 1994), 453.

8. Ferenc Vali, Bridge across the Bosporus (Baltimore, Md.: Johns Hopkins University Press, 1971), 228. 
a decade after the Second World War, there was no reason why their warming relationship could not have made further progress. This is what could reasonably have been expected in the early 1950s, given both countries' fear of the Soviet Union and commitment to the Western alliance. However, when the vital interests of one seemed to be threatened by the other, as happened with the Cyprus issue in 1954 and 1955, the progress attained in GreekTurkish reconciliation and collaboration was lost.

\section{The Outbreak of the Cyprus Conflict and Deteriorating Relations between the Two NATO Allies}

At the end of the 1940s, with decolonization pressures, the issue of Cyprus emerged as the major bone of contention dividing the Greeks, the British, and the Turks. Each of the three NATO countries felt that their vital interests were at stake, and they soon entered into a dangerous collision course. The task for the United States was to carve out policies that would lead to peaceful settlement that would not rupture the cohesiveness of the strategic southern flank of NATO. The decision of Greece to internationalize the issue in 1954, as well as the start of EOKA's (National Organization of Cypriot Fighters) violent struggle on Cyprus in 1955, led Britain to organize the London Tripartite Conference with the participation of Greece and Turkey at the end of August 1955.9

As the conference commenced in London, on 6-7 September 1955 unruly Turkish citizen groups, with the backing of the Menderes government in Ankara (as proved later during his trial in 1961), attacked the property and persons of the Greek minority in Istanbul. The damage was considerable in blood and treasure. ${ }^{10}$

The Papagos government in Athens was incensed and ordered back to Greece all the Greek officers serving in a mixed NATO regional command

9. The conference led nowhere, as Greece insisted that self-government should not exclude enosis (union of Cyprus and Greece) in the long run. Turkey preferred the continuation of British rule on Cyprus, but if any change was to come in the island's status, Cyprus ought to revert to Turkey because of prior possession, geographic contiguity, and the presence of the 18 percent Turkish Cypriot minority. Thus the only compromise Turkey appeared to be willing to make was based on the policy of taksim, Greek-Turkish partition of Cyprus.

10. Alexandris. 
operating in Izmir. The Greek side expected a strong official US reaction. Instead, the American reaction was mild and did not satisfy the Greeks. The stance adopted by Secretary of State John Foster Dulles and announced in a letter of 18 September 1955_of keeping the United States at an equal distance from each country-disappointed and frustrated the Greeks. Secretary Dulles sent identical letters to the prime ministers of Greece and Turkey deploring antagonism between the two countries and calling for restraint. ${ }^{11}$ The message the United States was sending was to be repeated many times during the coming years: that the Cyprus problem, as well as bilateral problems between the countries, were relatively unimportant and had to be subordinated to the real danger, which continued to be the communist infiltration and exploitation of the weakness in the southeastern European region. As a result of the events of 1955, a considerable number of prosperous members of the Greek minority left Turkey for Greece.

American efforts on the Cyprus problem throughout the 1950s were designed to prevent Cyprus from disrupting the smooth functioning of the southeastern flank of NATO. The United States adopted a passive role toward Cyprus because it considered Cyprus within Britain's sphere of influence. It was mainly concerned that the Cyprus crisis could cause a deterioration of relations among three of its allies and weaken NATO. It did not object to either enosis (union with Greece) or taksim (partition between Greece and Turkey), provided that these solutions would be the result of trilateral negotiation. Hence, the United States opposed Greece's recourse to the United Nations and called for negotiations among interested parties. Thus the eventual Zurich-London settlement of 1959 between Greece and Turkey and the declaration of the independence of Cyprus in 1960 were welcome developments for the United States. Washington was pleased with the compromise agreements, which seemed to eliminate a serious friction point in the relations of its three allies.

When intercommunal disputes broke out almost two years after the independence of Cyprus, the United States decided to get involved in order to stop the civil strife in the island and the risk of a Greek-Turkish war. In June

11. Monteagle Stearns, Entangled Allies: US Policy Toward Greece and Turkey, and Cyprus (New York: Council of Foreign Relations, 1992), 25-30. 
1964 as the intercommunal violence was continuing, the Turkish government decided to intervene to protect its community and to strengthen its negotiating position to seek a better settlement.

Immediately, President Lyndon Johnson, in order to avoid a Turkish landing in Cyprus, which would have resulted in a Greek-Turkish war, sent a letter to Premier Inönü. In that letter worded in a rather undiplomatic style, Johnson declared that the United States would cease to support Turkey if the Turkish intervention in Cyprus could lead to an involvement of the Soviet Union. ${ }^{12}$ As a result, a Turkish landing on Cyprus did not take place, but Turks were deeply hurt as they realized that the United States was not as reliable an ally as they had thought, and Turkey began to reconsider its relations with the Soviet Union.

Having prevented a war between the two countries, the United States became convinced that the "independence" solution for Cyprus would not work and reached the conclusion that union with Greece would have been the best outcome. However, this was only to be achieved in return for Greece's territorial concessions to Turkey, which the United States was determined not to humiliate.

American mediation efforts based on the above ideas were formulated in summer 1964 in Geneva under Dean Acheson. The Acheson plan for the Cyprus solution would have provided for a dissolution of the state of Cyprus on the basis of a Greek-Turkish agreement, offering the annexation option to Greece while allowing, in compensation, a smaller but sizable portion of Cyprus to be administered by mainland Turkey. ${ }^{13}$

All the versions of the American plan could have been sold to the Greeks as enosis and to the Turks as taksim. The plan in the American eyes would have solved the problem of Cyprus permanently and would have been to the alliance's advantage. The island would have been retrieved from the status of a nonaligned state and placed within the NATO orbit, apportioned among the three NATO allies (as the British presence would have continued in its sovereign base areas in Cyprus.)

12. "Letters Exchanged between President Johnson and Prime Minister Inonu," Middle East Journal (1966): 387.

13. Sotiris Rizas, Union, Division, Independence: United States and Britain Seeking a Solution, 1963-1967 (in Greek) (Athens: Bivliorama, 2000), 127-9. 
In order for this solution to be achieved, Greece and Turkey would need to have agreed on the proposed terms (an apportionment of the territory of Cyprus) and would have to convince their respective communities on Cyprus of the benefits of the arrangement. On the first issue Greece could not accept the idea of making territorial concessions, even if it was only for a military base for Turkey of the size of the British base. Turkey, on the other side, sought a larger portion of the island for its military base, to include space for as many Turkish Cypriot civilians as possible.

On the second issue, the Turkish government did not face problems as the Turkish Cypriot community fully approved of Turkish actions. However, the Greek government had to secure the cooperation of the hard-to-control Cypriot president, Archbishop Makarios, who was in favor of enosis but did not wish to give up his nonaligned policy for Cyprus.

Greek prime minister George Papandreou himself faced an enormous problem, as he could not control Makarios, and it was therefore difficult for him to commit Makarios to Greek policy and at the same time persuade the Americans to achieve the best possible agreement with the Turks. So he was trapped between the Makarios policy and his own vague populist policy toward enosis.

During the serious crisis of 1963-4, the US administration became involved actively and with some arrogance to contain the conflict and to effect a new settlement in Cyprus between the two allies. But all its efforts came to no avail. The US handling of the Cyprus problem in 1964 was not successful for three reasons. First, the United States kept the problem within the NATO family, perceiving Greece and Turkey as being the countries that would be able to decide the fate of the island, and thus underestimated the power of the Cyprus government under Makarios, which refused to let those countries determine Cyprus's future. Second, the United States fought the symptoms rather the roots of the problem, as Washington continued to see the Cyprus problem as a Greek-Turkish thorn in the southeastern flank of NATO. Third, the United States did not appreciate that both Greece and Turkey considered Cyprus more important in their foreign policy priorities than NATO solidarity.

Three years later, in November 1967, a new crisis burst on Cyprus. The Turkish government threatened to retaliate with military intervention unless 
EOKA's chief, George Grivas, was removed from the island together with the ten thousand Greek mainland troops that had been infiltrated into Cyprus since 1964. American diplomacy became active again between Athens, Ankara, and Nicosia, and Cyrus Vance, as President Johnson's special representative, convinced George Papadopoulos_one of the leaders of the Junta regime established in Athens in April 1967-to remove Grivas and the Greek army division from Cyprus, a development that satisfied Turkey. ${ }^{14}$

Having experienced the unpleasant 1963-4 Geneva negotiations, in the 1967 crisis the Americans tried only to manage the crisis, which was an easy task, as the Greek side accepted quickly the Turkish demands.

Once the split between Athens and Nicosia came to a head, with the coup d'état by the Greek colonels in Cyprus in summer 1974, US diplomacy became active again. Its aim was to keep Greece and Turkey from clashing over Cyprus and harming the NATO flank. In 1974, the United States could not stop Turkey from intervening on the island, but as a general GreekTurkish war was avoided, the United States and particularly Secretary of State Henry Kissinger did not really care about the eventual outcome of the crisis. However, if the United States had acted actively in 1974 as it did in the 1963-4 and 1967 crises, it may be that it could have been able to prevent the outcome that still persists, although this is merely speculation in hindsight.

The Greek military regime orchestrated plans behind the scenes against Makarios in an effort to achieve enosis, the long-standing desire of Greece. The Junta was convinced that the United States would not allow Turkey to get involved in the island, but the coup against Makarios caused Turkish military intervention, as Turkey was determined in 1974 to protect its vital interests in the island. ${ }^{15}$

After the collapse of the Greek military regime in Athens, the new civilian government under Constantine Karamanlis could not really act effectively either diplomatically or militarily. At the diplomatic level, during the 1974

14. Claude Nicolet, United States Policy towards Cyprus, 1954-1974: Removing the Greek-Turkish Bone of Contention (Mannheim und Mohnesee, Germany: Bibliopolis Mannheim und Mohnesee, 2001), 361-3.

15. Suha Bölükbaşi, The Superpowers and the Third World: Turkish-American Relations and Cyprus (Lanham, NY: University Press of America, 1988), 195. 
Geneva conference, decisions needed to be approved by Makarios who, at that time, chose for himself the role of the victim of both sides (Greek and Turkish) and who even in face of the military defeat could not accept a compromise.

In the military arena, Karamanlis did not undertake the high risk of declaring war against Turkey, being aware of the real capabilities of the Greek forces. And at that particular time it was impossible to trust the high military officials. So as a protest of US ineffectiveness to stop Turkey, he withdrew Greece from the military wing of NATO.

Meanwhile, the strong Greek-American lobby in Congress began to put pressure on Turkey. In February 1975, Congress imposed an arms embargo on Turkey, on the grounds that American equipment had been misused in the Cyprus landing. The embargo stopped the delivery of arms already purchased by Turkey and the disbursement of $\$ 200$ million in grants. The action was vigorously opposed by the US administration, particularly by Secretary of State Kissinger, who argued that it would seriously weaken Turkey's defensive capability and thus damage the alliance. ${ }^{16}$

Turkey's reaction to the congressionally imposed US arms embargo came almost five months later. On 26 July 1975, Turkey suspended US operations at all military installations within Turkey. Eventually, the US arms embargo was lifted, in 1978. ${ }^{17}$

The results of the 1974 crisis were crucial for both Greece and Turkey. Both states realized that their vital US ally was motivated by its strategic considerations without taking into account the vital interests of each country. The American role in the Cyprus conflict during the decade from 1964 to 1974 significantly altered the Greek and Turkish perceptions of the role of the United States in Greek and Turkish national security. Both realized that NATO membership was not a panacea for all security contingencies. Both strove to decrease their dependency on the United States. Greece shifted its foreign policy to Western Europe, and Turkey improved its relations with the Soviet Union and other regional states.

16. Robert McDonald, "Alliance Problems in the Eastern Mediterranean-Greece, Turkey and Cyprus: Part II Prospects for Security in the Mediterranean," Adelphi Papers, no. 229 (1988): 61. 17. Bruce Kuniholm, "Turkey and the West since World War II," in Turkey between East and West, ed. Vojtech Mastny and Craig Nation (Boulder, Colo.: Westview, 1996), 57-8. 


\section{The Emergence of the Aegean Dispute and US Involvement after 1974}

In the second half of the 1970s, the center of the Greek-Turkish conflict shifted from Cyprus to the Aegean. ${ }^{18}$ In the light of its Cyprus experience, the Athens government was afraid that Ankara might be tempted to employ military force in this area. In order to avoid this, Greek diplomacy sought political and military assistance from the United States. The aim of the Greek strategy was both to get the United States to guarantee the territorial status quo in the Aegean and to allocate its military aid to Greece and Turkey in a manner that would not disrupt the regional balance of power.

As to US guarantees for the territorial status quo, Greek diplomatic efforts have not been particularly effective, although in 1976 the Karamanlis government obtained an official commitment from US Secretary of State Kissinger "that the United States would actively and unequivocally oppose either side seeking a military solution and will make major efforts to prevent such a course of action."19 This was the closest the Greeks ever got to an official guarantee for their borders with Turkey. In 1981, Prime Minister Andreas Papandreou ${ }^{20}$ went further by asking NATO to guarantee Greece's eastern

18. In late 1973, following the discovery of oil deposits off the southern shore of the island of Thasos in the northeastern part of the Aegean Sea, a number of jurisdictional issues were added to the already emotionally heavy Greek-Turkish agenda. The Aegean dispute is a composite term covering three separate but related issues between Greece and Turkey:

1. the dispute about sovereign rights over the Aegean continental shelf,

2. the question of the territorial sea limits claimed by each country, and

3. a dispute over military and civil air traffic control zones in the Aegean area.

Three other questions are intimately involved and must be considered in connection with the Aegean dispute: the remilitarization of the Greek islands of the eastern Aegean, the demilitarization of which was ordered by the Treaties of Lausanne (1923) and Paris (1947); the problem of minorities (the Greek orthodox minority of Istanbul and on the islands of Gockada, or Imvros, and Bozcada, or Tenedos); and the Muslim minority (mainly of Turkish origin) in Western Thrace. Greece recognizes as a problem only the delineation of the continental shelf and is in favor of a legal solution via the International Court of Justice, while Turkey prefers a political solution through bilateral negotiation. For details, see Tozun Bahcheli, Greek-Turkish Relations since 1955 (Boulder, Colo.: Westview, 1990), 129-69; Christos Rozakis, "The International Legal Status of the Aegean and the GreekTurkish Crisis," in Greek-Turkish Relations, 1923-1987 (in Greek), ed. Alexis Alexandris et al. (Athens: Gnosi, 1988), 269-492.

19. Dimitrios Bitsios, Beyond the Borders (in Greek) (Athens: Estia, 1983), 254.

20. In October 1981, PASOK, under Andreas Papandreou, came to power after having warned the Greek electorate in numerous speeches of the "Turkish threat." The search for allies against "Turkish 
borders. ${ }^{21}$ The Greek demand for border guarantees was repeated for some years but then shelved, as neither Washington nor NATO (let alone Turkey) was inclined to accept this kind of an arrangement.

Regarding the maintenance of the regional balance, the Greeks have been remarkably successful. Since 1978 it became an accepted practice for Congress to allocate military aid to Greece and Turkey in the ratio of sevento-ten. In other words, Congress has given to the Greeks 70 percent of the military assistance it provides to the considerably larger Turkish armed forces, in spite of Turkish protests and the occasional unwillingness of the US executive branch. ${ }^{22}$

Turkey, too, tried to advance its position in the bilateral dispute via NATO. The Turkish side constantly blocked the Greek reentry to NATO until 1980 and sought to internationalize the so-called Lemnos problem. ${ }^{23}$ Athens maintains that this strategically important island close to the Dardanelles may be militarized, thus stationing air force and army units on the island. Turkey quotes the Treaty of Lausanne (1923) and argues that this island must be demilitarized. The Lemnos problem is a part of the overall Greek-Turkish dispute pertaining to the military status of the Greek islands of the eastern Aegean. ${ }^{24}$ Ankara has successfully internationalized and NATOized this bilateral problem by preventing — to the dislike of the Greeks—an inclusion of Lemnos in all NATO exercises.

\footnotetext{
expansionism" became the prime goal of Greek foreign policy. In December 1981—only a few weeks after his triumphant election victory-Papandreou attended a NATO defense ministers meeting, where he stubbornly insisted on a guarantee by the alliance to shield Greece from aggression by Turkey. NATO members were not willing to agree to this demand, and the entire meeting ended in failure. For the first time in NATO's thirty-year history, no joint communiqué was issued. This was the most spectacular example of Papandreou's internalization strategy in NATO. See Van Coufoudakis, "PASOK and Greek-Turkish Relations" in Greece, 1981-1988: The Populist Decade, ed. Richard Clogg (New York: St. Martin's, 1993), 172-3.

21. Richard Clogg, "Greek-Turkish Relations in the Post-1974 Period," in The Greek-Turkish Conflict in the 1990s: Domestic and External Influences, ed. Dimitrios Konstas (London: Macmillan, 1991), 18; Gürel, 92.

22. Carol Migdalovitz, "Greece and Turkey: Current Foreign Aid Issues," CRS Issue Brief (1995), 2 .

23. Nikos Barbarousis, "The Militarization of Limnos," Tetradia, no. 21 (in Greek) (1985): 79-87. 24. James Brown, Delicately Poised Allies: Greece and Turkey: Problems, Policy Choices, and Mediterranean Security (London: Brassey's, 1991), 13-4; Stavros Ligeros, "The NATO Dimension of the Greek-Turkish Dispute," Tetradia, no. 25 (Greek) (1989): 53-62.
} 
The Greek-Turkish disputes over the limits of the continental shelf in 1976 and 1987 caused serious tension in the Aegean and further worsened the relations between Greece and Turkey. During the 1976 crisis neither party attempted to involve the United States. After the end of the crisis, the Greek government launched two separate appeals, one in the Security Council and another to the International Court of Justice in an effort to internationalize the issue as much as possible and to involve as many international players as possible. ${ }^{25}$ The Turkish side asked for bilateral negotiations, a proposal that Greece rejected.

For the next six years, the Aegean continental shelf dispute remained a problem in Greek-Turkish relations; there was no real crisis, but no effort to solve the problem, either. Then in 1987, the issue of the shelf brought Turkey and Greece once again close to conflict. This time Greece tried to mobilize NATO in an effort to resolve the crisis. Papandreou went further, by holding the United States responsible for the crisis. In an effort to pressure the United States, Papandreou ordered the suspension of operations of communications facilities at the American base in Nea Makri and promptly dispatched his foreign minister, Karolos Papoulias, to Sofia to brief the Bulgarian leader, Theodor Zivkof. In a calculated snub, the ambassadors of Warsaw Pact countries in Athens were briefed on the crisis in advance of their NATO counterparts. ${ }^{26}$ Eventually, with the mediation efforts of the NATO secretarygeneral, the tension subsided.

The Aegean dispute has become the primary source of tension between the two allies. Each side has developed and structured its arguments over the Aegean issues with no real intention or will to move even slightly toward a peaceful solution. The United States has followed a hands-off policy intended to project the alliance impartiality and has encouraged both nations to settle their disputes bilaterally. It attempted neither to take a more active role as a mediator nor to take public positions on the bilateral dispute.

25. The Greek foreign minister asked the American ambassador in Greece, Jack Kubish, that the United States play "fair" and not act behind the scenes in favor of Turkey during the discussions at the Security Council. Bitsios, 82.

26. Clogg, "Greek-Turkish Relations," 12-26; "Aegean and Turkish Provocativeness," Ptisi (MayJune 1987): 4. 


\section{New Phase: Greek-Turkish Disputes in the post-Cold War Era}

The end of the Cold War brought about significant changes and new challenges in the foreign policy priorities for Greece, Turkey, and the United States. The bilateral problems between the two allies as well as the Cyprus issue remained intact, and relations further deteriorated during the last decade of the twentieth century.

US policy toward the dispute did not change substantially after the end of the Cold War. The United States has continued to seek to preserve stability in the eastern Mediterranean, a region bordered with conflict zones, and to prevent NATO from being embroiled in local controversies. In order to achieve these goals, the United States tried to remain "neutral" and worked to resolve disputes between the two NATO members. Compared to the period between 1974 and 1989, the United States has since the end of the Cold War been more active. The eruption of the Imia/Kardak crisis of 1995 was stopped only by American intervention, and the threatened deployment of the Russian S-300 missiles in Cyprus did not take place after intensive American mediation. A new important parameter in this triangular relationship in the 1990s was the European Union, whose policies were welcomed from the American side. All the countries involved in the dispute have political links with the EU. Greece has been a member for some years, Cyprus became a full member in May 2004, and Turkey is a candidate member. A search for a solution of the Cyprus problem and the Aegean dispute through EU diplomatic channels and ideas is under discussion and consideration.

The Imia/Kardak crisis was the first "hot" incident in the Aegean in the post-Cold War era. A small Turkish cargo ship went aground in late December 1995 less than four miles off the Turkish coast on an uninhabited rocky islet group, called Imia by the Greeks and Kardak by the Turks. The Turkish captain refused to have his vessel rescued by Greek authorities, claiming that he was in Turkish territorial waters. ${ }^{27}$ The two foreign ministries thereafter exchanged information, holding to differing positions on the islets sovereignty but refraining from making confrontational demands or going public.

One month later this event created more publicity as the local Greek mayor raised the Greek flag over the islet. Turkish news reporters took to the scene Review of Balkan Studies, no. 6 (2001): 172. 
from a helicopter and hoisted a Turkish flag in place of the Greek one. Media in each country exaggerated the issue. Both governments dispatched warships, and the Turks landed a detachment of marines on one of the islets. ${ }^{28}$

Washington moved to defuse the crisis. President Bill Clinton placed calls for a peaceful outcome, and Ambassador Richard Holbrooke began intense mediation. American diplomatic efforts were targeted to bring the situation back to its former status and succeeded. ${ }^{29}$ The US position was that "in case of not opening fire against the Turkish soldiers and if the Greek military force withdraws its presence and the Greek flag, the Turkish military forces will do the same." The statement from the United States emphasized that: "the party that shoots the first bullet will find the United States against it." 30 Finally both sides withdrew, and a return to the status quo ante was achieved. ${ }^{31}$

The issue arose just after the accidental grounding of the Turkish ship. Until then there were no doubts about the sovereignty of these islets, which according to a Turkish-Italian document of 1932 specifically listed these islets as belonging at the time to the Italians, which means sovereignty would have been transferred from Italy to Greece after World War II under the terms of the 1947 Paris Treaty. ${ }^{32}$

28. Carol Migdalovitz, "Greece and Turkey: Aegean Issues-Background and Recent Developments," CRS Issue Brief (1997): 4; Alkis Kourkoulas, Imia: A Critical Approach of Turkish Policy (in Greek) (Athens: Sideris, 1997).

29. Aksu, "Turkish-Greek Relations," 175; Krateros Ioannou, "A Tale of Two Islets: The Imia Incident between Greece and Turkey," Thesis 1, no. 1 (1997): 1-7.

30. Aksu, "Turkish-Greek Relations," 174; James Wilkinson, "The United States, Turkey and Greece-Three's a Crowd," in Turkey's Transformation and American Policy, ed. Morton Abramovitz (New York: Century Foundation, 2000), 185-218.

31. During the crisis, Kostas Simitis became the Greek prime minister after the resignation of the ill Andreas Papandreou. Simitis at that time did not have full control of the government, and to a certain degree there was lack of coordination. On the other hand, in Turkey Prime Minister Tansu Ciller ruled a coalition government and was in the middle of an effort to form a new government after the elections of December 1995. The crisis might have taken place even if both states had more stable governments, but domestic instability may have been a part of the escalation of the crisis. See "Nea Sinora Zitoun sto Agaio: Apeili Thermou Episodiou" (They demand new borders in the Aegean: Threat of a new hot incident), Ta Nea, 30 January 1996, 10; "Telos Tholo: Hmiselinos sto Nisaki mas" (Unclear end: The crescent in our small island), Elepherotipia, 31 January 1996, 7-9; “To Sxedio tou Polemou" (The plan of the war), Eleftherotypia, 4 February 1996, 7; "Ti Kanoume an xana Ktipisei i Tourkia" (What do we do if Turkey attacks?), Ta Nea, 1 February 1996, 10. Also see Turkish Daily News, 31 January 1996, 4, and 2 February 996, 6-8.

32. The Turkish government, however, asserted that this Italian-Turkish protocol had never entered into force and that the rocks themselves had been "registered" by the onshore Turkish province of Mugla. See Yuksek Inan and Sertac Başeren, Status of Kardak Rocks (in Turkish), unpublished Turkish government report, Ankara, 1997. 
In the period that followed, the Turkish government refused to concede on this issue but also insisted that there are "gray zones" in the Aegean and numerous small islets or rocks whose sovereignty is unclear despite Greek claims. ${ }^{33}$ Ankara did not provide specifics, but neither did it abandon the position, which garnered broad public credence in Turkey. ${ }^{34}$ This angered Greek public opinion enormously. The Turkish government was seen to have embarked on a new and more aggressive course, threatening to redraw boundaries throughout the Aegean at Greece's expense. ${ }^{35}$

This Greek-Turkish crisis showed that when a situation is escalated, the Greek and Turkish governments have been unable or unwilling to deal directly with each other, and the mission has fallen to the Americans. During the crisis, both sides followed an adamant position and were determined not to lose face, even if the consequence could have been war. When the worst was avoided, both decided in favor of a peaceful resolution, recognizing that a war was not in either side's national interest.

A similar situation took place after the decision of the Cyprus government in January 1997 to contract with Russia for the purchase of S-300 missiles, an antiaircraft system similar to the American Patriot missile. ${ }^{36}$ The Turks reacted strongly. They denounced the missile purchase as unwarranted escalation, denied there was any threat from Turkish planes, and described the

33. See Melek Firat, "Greek Foreign Policy in the Post-Cold War Era," in Neighbors of Turkey (in Turkish), ed. Mustafa Türkeş and Ilber Uzgel (Ankara: Imge, 2002), 56-9.

34. "Me Polemo mas Fovizei i Tourkia" (Turkey threatens us with war), Elepherotipia, 5 February $1996,2$.

35. "Neo Thema Vazi i Tourkia" (Turkey raises new issue), Elepherotipia, 6 February 1996, 2.

36. The purchase of the missiles was part of the implementation of a military modernization program designed to produce quantitative and qualitative improvements in the country's defense capabilities vis-à-vis Turkey, seen as the single major external threat. In addition to a deterrence strategy, based on a military cooperation agreement and common defense doctrine instituted with Greece in 1993, Greek Cypriots opened an air base at Paphos and completed a $\$ 425$-million purchase agreement for thirty Russian S-300 medium-range, surface-to-air missiles. According to the Greek Cypriots, this military strategy would reinforce their position in the intercommunal talks and put some pressure on the international community to achieve the withdrawal or even a serious reduction of the Turkish troops. It would also guarantee the security of the Greek-Cypriot population, as they lived under the shadow of a permanent menace. See "S-300: To Thriller Sinexizetai" (S-300: Thriller carries on), To Vima, 29 November 1998, A32; "S-300: To Xroniko mias Proanagelthisas Egatastasis" (S-300: The events for a preannounced deployment), To Vima, 29 March 29 1998, A24; “Tous S-300 Tous Xehasate?" (Did you forget the S-300?), To Vima, 15 November 1998, A30; "S-300: O Telikos Giros" (S-300: The final round), Eletherotipia, 8 November 1998, 17; Turkish Probe, November 6 1998, 4; Turkish Probe, 8 December 1998, 3-4. 
S-300 missiles as jeopardizing not only Turkish Cypriots but the security of Turkey itself. 37 Ankara said it would "not tolerate" deployment, and the general staff was directed to take "additional military measures." Washington decried both the deployment and the threat of military action in response. ${ }^{38}$

Cyprus President Glafkos Clerides postponed implementation twice in 1998 and in December of that year announced a decision, which had been taken in consultation with Athens, to cancel the deployment. The missiles were instead to be sent to Crete. The Clerides government, which backed down despite strong domestic support, received intense pressure from the United States and the Europeans and was concerned about possible adverse effects on Cyprus's pending application for EU membership. Although statements from Athens were carefully phrased to maintain the credibility of the "joint defense doctrine," the Greek government did not oppose deployment, presumably because it did not desire the escalation of a new Greek-Turkish crisis, which could have been caused by Turkish military actions. ${ }^{39}$

\section{Conclusion}

During the post-Cold War era the United States was successful in its crisis management role, which preserved the stability of NATO in southeastern Europe and avoided the unthinkable: the two allies going to war. On the other hand, US efforts to mediate for a solution proved fruitless. Washington has put itself forth as the premier honest broker, has used special envoys as its primary weapons, and has focused principally on kick-off negotiations, though its activism has not yet achieved its stated goal. The relative ineffectiveness of the world's only superpower in this specific peacekeeping enterprise stems to a large extent from US political considerations. This is always a disadvantage in the US mediating efforts.

37. Henze Kramer, “The Cyprus Problem and European Security," Survival 39, no. 3 (1997): 19; Hasan Ünal, "Missiles off to Crete, Is Peace Any Nearer?" Strategist (February-March 1999): 35-7; Gulden Ayman, "A Case of Brinkmanship: S-300 Missile Crisis," Turkish Review of Balkan Studies, no. 7 (2002): 5-34.

38. Washington had additional concerns. The possible deployment of Russian weapons on the already overly militarized island was an undesirable development for the American side. See Nicholas Berns, interview, at www.ana.gr/hermes/1998/sep/interview/htm, accessed 30 November 2003. 39. Eletherotipia, 6 September 1998. 
On the other side, both Greece and Turkey have perceptions of a US role that are completely different. The Greeks ask from the Americans support and understanding for their problems; the Turks, on the other hand, think that they can deal with the Greeks by themselves. The common perception for Greece and Turkey is that both think that the United States is in favor of the other.

Additionally, the United States has to a certain degree put pressure on the two parties but there are clear and definite limits. The whole history of the disputes and the American role have shown that whatever the Americans propose, it is the two governments that should have the political courage and will to decide and commit. The search for a more effective US role in GreekTurkish disputes will continue for American decision makers. At least keeping and strengthening Greek-Turkish détente is a positive element. Furthermore, the involvement of the EU may provide an opportunity for the United States to disengage itself to a certain extent from bilateral Greek-Turkish disputes. 